Article

\title{
Social Inclusion and Integrative Practices
}

David Cappo and Fiona Verity

School of Social and Policy Studies, Flinders University, Bedford Park, SA 5042, Australia;

E-Mails: david.cappo@flinders.edu.au (D.C.), fiona.verity@flinders.edu.au (F.V.); Fax: +61-8-8201-3350 (F.V.)

\section{How to Cite this Article}

Cappo, D., \& Verity, F. (2014). Social Inclusion and Integrative Practices. Social Inclusion, 2(1), 24-33.

\section{Copyrights}

(C) 2014 by the authors; licensee Cogitatio (Lisbon, Portugal). This article is licensed under a Creative Commons Attribution 4.0 International License (CC BY).

\section{Published by:}

\section{COGITATIO}

www.cogitatiopress.com

\section{About the Journal}

Social Inclusion is a peer-reviewed open access journal which provides academics and policy-makers with a forum to discuss and promote a more socially inclusive society. The journal encourages researchers to publish their results on topics concerning social and cultural cohesiveness, marginalized social groups, social stratification, minority-majority interaction, cultural diversity, national identity, and core-periphery relations, while making significant contributions to the understanding and enhancement of social inclusion worldwide.

www.cogitatiopress.com/socialinclusion

\section{Editor-in-Chief}

Professor Ulf R. Hedetoft, Faculty of Humanities, University of Copenhagen, Denmark

\section{Managing Editor}

Mr. António Vieira, Social Inclusion, Cogitatio Press, Portugal 
Article

\title{
Social Inclusion and Integrative Practices
}

\author{
David Cappo and Fiona Verity* \\ School of Social and Policy Studies, Flinders University, Bedford Park, SA 5042, Australia; \\ E-Mails: david.cappo@flinders.edu.au (D.C.), fiona.verity@flinders.edu.au (F.V.); Fax: +61-8-8201-3350 (F.V.) \\ * Corresponding author
}

Submitted: 21 April 2014 | Accepted: 27 May 2014 | Published: 26 June 2014

\begin{abstract}
With the passage of time valuable lessons have been learnt about both effective practices for program and system integration and the sizable barriers, including the challenges in sustaining constructive integration. This paper is a reflection on sustainable integrative practices and is grounded in the direct experience of one of the authors, who held the post of the South Australian Social Inclusion Commissioner. We reflect upon the structure and mechanism of the South Australian Social Inclusion Initiative (2002-2011) as well as using a case study of a successful integrative program of the Social Inclusion Initiative, a program in South Australia's School Retention Action Plan 2004 Making the Connections (South Australian Social Inclusion Board, 2004) that was implemented to improve school retention. The case study draws out salient factors of clear rationale, coordination, collaboration, communication, team work and trust as skills and ingredients to bring about integration in policy and programs. While the integration literature affirms that these ingredients are primary skills for the development of an integrative framework, we also assert that they are not enough for successful and sustained integration. Absent from much of the literature is a discussion about the use of power and the manner in which horizontal integrative work occurs. We take up this theme to draw out some implications for analysis of sustainable integrative practices.
\end{abstract}

\section{Keywords}

education; integration; integrative practices; school retention; social inclusion

Issue

This article is part of a regular issue of Social Inclusion, edited by Professor Ulf R. Hedetoft (University of Copenhagen, Denmark).

(C) 2014 by the authors; licensee Cogitatio (Lisbon, Portugal). This article is licensed under a Creative Commons Attribution 4.0 International License (CC BY).

\section{Introduction}

For at least three to four decades, institutions in many countries have implemented variants of policies to integrate systems and programs, using a range of models and nomenclature including 'social inclusion', 'joined up government' and 'post national integration' in reference to the European Union (Lynn, 1998; De Lombaerde \& lapadre, 2008; Eriksen \& Fossum, 1999; Mulgan, 2005). The quest to join parts together -and this will look different depending on the context and players-is a reaction to institutional factors and external forces (Christensen \& Lægreid, 2007). In broad terms there has been a convergence in perspectives that 'in- tegration' will re-enable institutions to meet their agendas in times of quickening social change, and in the face of competing demands on resource use (Fine, Pancharatnam, \& Thomson, 2000; Ragan, 2003; Martin \& Austen, 1999). Our now complex systems and the case for integration, emerge from the historical course of legal/rational institutions and impacts of contemporary processes of global and technological change (Christensen \& Lægreid, 2007; Corbett \& Noyes, 2008).

Early in 2013 the United Kingdom Coalition Government's Secretary of State, Eric Pickles, gave a speech entitled "Uniting our Communities: Integration in 2013" (Pickles, 2013). Throughout his speech Pickles assigns to 'integration' a sizeable load; as the means to work 
for tolerance, social cohesion and wellbeing. The message is that through locality level 'integration', or joining of the activities and plans of diverse organisations and communities, complex social issues are more able to be addressed. Of course, as the Blair Government's Social Exclusion and whole of government agenda shows, integration policies are not exclusively the province of the conservative side of politics, and the uptake has not been restricted to matters of migration and population change, or the constitution of social services (Mulgan, 2005, 2009). Integration discourses and practices are now firmly embedded in the fields of social welfare, psychotherapy, psychology, interdisciplinary education, regional planning, economics, organisational theory, management, business, public policy and peace keeping (Black, 2013; Corbett \& Noyes, 2008; Martin \& Austen, 1999; Rousseau, 2011; Wilber, 2000).

In the human services, integration has been pursued for multiple reasons; as a way to expand holistic and reflexive thinking about the contributors to social issues; tighten connections in complex multi-sector delivery systems; and strengthen collaborative capacity to generate approaches that transcend what currently exists (Corbett \& Noyes, 2008; Fine, Pancharatnam, \& Thomson, 2000; Jennings \& Krane, 1994; Ragan, 2003). Integration as an outcome and integrative practices as a process, have mixed assessment. There is a view integrative practices have delivered valuable outcomes, in part, because they have challenged the status quo, both in thinking and in practice. For example Ragan (2003, p. 8) observes "the larger purpose is to improve outcomes for individuals and families through a more holistic approach to service delivery". More coherent, improved delivery systems are seen to be the result (Corbett \& Noyes, 2008; Patterson, 2011a).

There is a robust and compelling critique that the use of the concept 'integration' can be hollow and little more than fashionable window dressing. This argument has a number of aspects. One is that integration can be pitched as progressive, but in practice, can be a policy tool limited in tackling substantive matters of inequity and social injustice. Just whose interests and values dominate in integrative processes is an important question (Davies, 2009; Fine, Pancharatnam, \& Thomson, 2000). This critique of integration is evocative of Raymond Plant's (2009) analysis of the presentation of a consensual and unitary 'community' in public policy, where the ideological dimensions of a contested concept are under acknowledged (Bryson \& Mowbray, 1981). Furthermore, integration is a response to the conditions created by the neo-liberal state itself through policies of outsourcing and privatisation (Christensen \& Lægreid, 2007, p. 1059). For instance an increasing Australian not for profit sector (Australian Productivity Commission, 2010), together with the for-profit sector perform functions once undertaken by governments (Bryson \& Verity, 2009). The ensuing challenges for 'system' coherence and interagency work are well documented (Christensen \& Lægreid, 2007). Is sustainable integration a visionary way forward, a band aid, or simply unattainable?

Moreover integration consumes time, goodwill and economic resources and the phenomena of 'integration fatigue' and 'integration confusion' has been noted by many writers including Hartman and Squires (2009) on racial integration initiatives, and Boutellis (2013) in analyzing the United Nations, and this message is a recurring media commentary on the situation in the European Union. In short integration can have high transaction costs (Fine, Pancharatnam, \& Thomson, 2000). There can be loss of identity for programmes in integrated structures which can be experienced as dispiriting, especially if the integration case is unconvincing and there has been little active participation in the change (Boutellis, 2013). Patterson (2011b, p. 83) for example, writes of the 'suspicion and trepidation' that can greet short term social inclusion pilot programmes when faced with expectations for substantial change, but no assurance about program stability.

Boutellis' (2013) analysis of the United Nations is especially instructive. His report entitled 'Driving the System Apart?' discusses the unintended consequences of twenty years of UN integration effort. He notes that in spite of the UN's institutional commitment and policy and programme framework for integration:

...the UN integration agenda faces a number of obstacles that threaten to erase some of the hardwon gains. There are signs of integration fatigue from various corners of the organization, due in part to higher-than-expected transaction costs, the lack of incentives and rewards for integration, the difficulty of demonstrating and communicating the outcomes and impacts of integrated planning processes, and continuing structural impediments to fully realizing the "integration promise." (Boutellis, 2013, p. 1)

Is it possible to identify the essential aspects of sustainable integrative practices? A reading of the literature on integrative practices points to the need for clear definitions and case for integration, and moreover one that can be communicated. In addition, it would seem salient factors are a concerted effort over time to nurture institutional practices where holistic and integrative thinking becomes a cultural habit, and where there is engagement in dialogue and relational exchanges, both within and external to the organization (Corbett \& Noyes, 2008; Fine, Pancharatnam, \& Thomson, 2000; Ragan, 2003). Ragan (2003, p. 17) in his study of human service integration in North America, identified relevant variables or integration 'success factors' that he groups by the headings of employee and leadership qualities, organisational cultural varia- 
bles, and a strengths-based, community orientated practice. He reflects on the need for rigorous evidence about the impacts of integration over time and for a period of time to 'bed down' change (Ragan, 2003). Managing the delicate balance of implementing administrative change with relationship engagement are key areas discussed by Corbett and Noyes (2008).

Against this background what we aim to do in this paper is explore the question of mechanisms for sustainable integrative practices. We do this through a focus on the Social Inclusion Initiative (2002-2011) in the sub national state of South Australia that used an integrative paradigm in its operation and in its development of programs. As a case study we will look specifically at the implementation of a program called Innovative Community Action Networks (ICANs) that was developed through the use of integrative practices. One of this paper's authors formerly held the role of the South Australian State Commissioner for Social Inclusion and chaired the Social Inclusion Board. He brings an insider perspective to this analysis. The South Australian Social Inclusion Initiative (2002-2011) is an example of integrative work. It is but one model, but a model deemed by writers such as Newman, Biedrzycki, Patterson and Baum (2007) and Patterson (2011b) to be a successful one providing invaluable lessons about integration processes. It also was an initiative that had its critics, for example, that it did not go far enough in pursuing a social justice agenda (Horsell, 2010). It was brought to an end in 2011 by a political agenda with the change of the head of government.

The material used in this paper is drawn from academic literature and evaluation reports about the ICANs and the SA Social Inclusion Initiative, together with the recollections and assessment of the former South Australian State Commissioner for Social Inclusion. Although mindful of the criticisms of integrative work, we write based on the premise that it can produce benefits. Thinking in this way brings to the foreground the interdependency of variables that contribute to social good and constitute the determinants of social issues (Ward, Meyer, Verity, Gill, \& Luong, 2011). We share with writers such as Corbett and Noyes (2008, p. 15) the position that integration is best seen as a 'dynamic' and 'relational change orientated' process, rather than the delivery of predetermined organisational or system structural change following a template, or in Martin and Austin's terms, an 'algorithm' (1999). Hence our emphasis on use of the term 'integrative practices'. We begin with a brief overview of the South Australian Social Inclusion Initiative.

\section{The Social Inclusion Initiative}

In 2002 the South Australian Labor Government headed by Premier Mike Rann (2002-2011) who also had the role of Minister for Social Inclusion (the first person to hold such a Ministerial position in Australia), established the Social Inclusion Initiative (SII) immediately upon coming to office, and gave it a mandate to develop integrated (joined up) policy and programs (South Australian Labor Party, 2002). At the urging of the South Australian Premier, the Federal Commonwealth Government, under the Prime Ministership of Kevin Rudd, also introduced a Social Inclusion Board, in 2007. However, this Federal Commonwealth Board's role was limited to that of an advisory board, while the SA Social Inclusion Board had executive power to form social inclusion policy for presentation to Cabinet, and to monitor and evaluate the implementation of social inclusion policy by government departments and community organisations.

The SII had two champions, namely, the Premier as head of government, and the Chair of the Social Inclusion Board and later Commissioner for Social Inclusion. The Social Inclusion Board was responsible only to the Premier, and had an executive body, the Social Inclusion Unit (a body of 20 staff at its strongest) to assist it develop policy and assist in implementation. This Unit, situated within the Department of Premier and Cabinet, was directly and independently supervised by the Chair of the Board, from outside the government's departmental system. This was a unique arrangement emphasising the authority and independence of both the Board and Unit. It was a clear signal that the power base established by the head of government and the Chair/Commissioner for Social Inclusion could bypass normal bureaucratic lines of authority, if needed, to achieve policy integration and effective implementation.

Why integrated policy and program? Because the head of government and the leaders of the SII determined that the SII needed to focus on people/communities who had complex and multi layered needs in their lives that were barriers to their social and economic participation (Cappo, 2002). This necessitated a strategy that understood that social issues were, in the main, joined up, therefore policy and program responses to those social issues also needed to be joined up and integrated if targets were to be achieved. As Newman, Biedrzycki, Patterson and Baum, authors of a rapid appraisal case study of the SII, note:

In the early days of the SII it was recognised that a significant constraint to tackling social exclusion would be the traditional public sector approach to addressing issues predominately by individual agencies or by Ministerial portfolio area. (2007, p. 59)

The Social Inclusion Board and Unit had the delegated power of the head of government to work independently (the SII used the expression 'providing independent advice while embedded in government') and developed policy as they saw fit to achieve outcomes for the community and government, on specific 'refer- 
ences' given to it by government, from time to time. When approved of by Cabinet (all SII integrated policies presented to Cabinet in the nearly ten year life of the SII were approved by Cabinet) the role of the SII was to assist government departments in applying the integrated policies across the departmental lines of government and to initiate the removal of bureaucratic or programmatic barriers to policy and program delivery. The Board and Unit worked closely with Treasury officials in order to ensure that social inclusion plans were robust, able to be funded, and had well developed evaluation processes presented to Cabinet for approval. The 'references' given by the Government to the Social Inclusion Board e.g. reduce rough sleeper homelessness by $50 \%$ by 2010 (a reduction that was achieved a year ahead of schedule in the inner City of Adelaide, the Capital City of the State of South Australia), significantly increase the school retention rate, undertake a major reform the mental health system, to name but a few, were 'references' that all required joined up integrated work.

\section{The Applied Understanding of 'Social Inclusion'}

While the SA Labor Premier made the decision that the concept and policy 'filter' of social inclusion was to be used in South Australia to address specifically identified social problems, he left the process of unpacking the concept of social inclusion to the SII itself. The South Australian Social Inclusion Board reflected upon definitions already in the literature and focused on key concepts and words within the broad understanding of the definitions of social inclusion, such as participation, access to opportunity, building capability, increasing wellbeing. At an early meeting of the Social Inclusion Board the Chair stated, 'we could define social exclusion as the process of being shut out from the social, economic, political and cultural systems which contribute to the integration of a person into community' (Newman, Biedrzycki, Patterson, \& Baum, 2007, p. 11).

The Social Inclusion Board was mindful that the concepts of social inclusion/exclusion were contested with debates and questions about what constitutes exclusion; whether the social inclusion emphasis should be about paid employment or participation in a range of political processes, as well as questions about the relationship between poverty, employment and participation in society (Bevir, 2009). As Bevir writes: '...some critics argue that the very concept of social inclusion is profoundly flawed'...[placing]'...too much emphasis on who is excluded rather than who is doing the excluding' (2009, p. 195). At the heart of this assertion is the view that a social inclusion emphasis on increasing opportunity for citizens to 'participate' in society can shift the social policy focus away from fundamental issues of inequality and redistribution of wealth, particularly as no matter how much 'inclusion', class divides in a capitalist economy and social system maintain inequal- ity (Levitas, 2005). Gray argues that 'Inclusion stands to social liberalism as distributive equality stands to social democracy' (2000, p. 21).

From another perspective Koikkalainen asserts that the shift of emphasis created by a social inclusion approach '...is not so much about securing an even distribution of material income as it is about achieving a tolerably even distribution of opportunities (emphasis in original)-equality in terms of agency, participation and memberships in beneficial networks' (2011, p. 455). Certainly in the South Australian application of the SII, social inclusion at the sub-national level had a focus on the provision of services and programs and was an addition to the ongoing work of wealth redistribution on a national level, where the Federal government has responsibility for major fiscal and monetary policy.

Cognisant of social inclusion's conceptual contestation, underpinning the Board's work was an understanding that groups of people within the broad community were excluded from an active and dignified participation in the economic and social life of the community. Barriers and obstacles existed both structurally and personally that prevented some people and groups of people from living out their active citizenship. The Social Inclusion Board saw as its primary task the removal of these barriers and to provide people in disadvantage with access to secure housing, learning and employment, health and other services, social support and connections, in order to participate as fully as possible. The wide range of these areas, coupled with the complex needs of the most disadvantaged, which were the focus of the SII, led necessarily to the Board centring its work in joined up, integrative policy development (Cappo, 2002; South Australian Social Inclusion Board, 2009).

\section{Making the Connections: ICANs}

Removing barriers which prevented groups of people from engaging in education was a specific agenda for the Social Inclusion Board (Newman, Biedrzycki, Patterson, \& Baum, 2007). The action strategy developed by the Social Inclusion Board was titled Making the Connections (2004). This included aiming to increase South Australia's poor school retention rate which had been trending lower than the Australian average, and had hovered around 67\% for the years 1999-2003 (South Australian Social Inclusion Board, 2004). As Stehlik and Patterson say '...poorer educational outcomes can be a contributing factor to greater social exclusion as those with little education are consigned to low paying, unskilled and precarious jobs or no jobs, experience poorer health outcomes and struggle to make ends meet on minimum incomes' (2011, pp. 6-7).

Making the Connections was conceptualised and implemented as a whole of government integrated strategy; it brought together a range of government 
departments (Education, Health, Families and Community Services, Aboriginal Affairs, Justice and Further Education and Training) in formulating one overall plan and implementing 41 action plan strategies (2004). Patterson notes:

From the outset, the Social Inclusion Board stressed that 'school retention' had to be seen as a wholeof-government and community issue if there was to be real change to systems of lasting benefit for young people, rather than being a problem solely for the institution of education to address. The Board's approach was to ensure that other agencies and local communities became involved through 'joined up' working that recognised and supported young people's engagement in learning. (2011a, p. 10)

A 'paradigm shift' needed to occur that placed the responsibility for this group of vulnerable students not only with the school or the education department and its bureaucracy but with the broad community, and secondly, power and decision making about solving the school retention problem needed to be shifted to the students themselves and the community, away from the education bureaucracy. Besides the Education Department needing to work with the Social Inclusion Board and Unit, integrated policy development to respond to school retention rates, required non Education Departments dealing with such issues as housing or juvenile justice to see that they were an integral part of the school retention plan.

The Innovative Community Action Networks (ICANs) are one of the most successful of the 41 action plan initiatives (Patterson, 2011a). ICANS are designed to be regionally based local committees with power and resources to understand and respond to local school retention problems. The ICANs receive annual funding from the State Education Minister to produce innovative and integrative ways to reengage students with learning and each has a high degree of autonomy in the allocation of their funds. Normal reporting procedures are in place to account in a transparent manner for public funds. Each regional ICAN has a unique membership which comprises young people and families, community leaders, business leaders, and others with an interest in local issues, and who have capacity to give of their voluntary time to the ICAN work (Patterson, 2011a; Koen \& Duigan, 2008, 2011).

The focus is young people who are disengaging from education and each regional ICAN addresses different local circumstances, with its own devised innovative approaches. The key is to establish reconnection of vulnerable young people with some type of suitable learning, as an opening to possibilities in future paid work, continued higher education and ongoing personal development. Besides individual learning plans for each ICAN student, this reconnection may be school based or outside of school structures (Koen \& Duigan, 2008, 2011; Patterson, 2011a). As noted above, their reason for non-school attendance is multiple and interconnected and require a joined up and integrated approach if the young person is to be successfully reengaged with learning.

Community engagement was also an essential part of the SII integrated policy work and was crucial in the ICAN work (South Australian Social Inclusion Board, 2009). Community consultation is common place in contemporary times in most levels of policy development. However, the term 'community consultation' has also become a pejorative term, alluding to the perception of superficial consultation by bureaucrats doing little more than going through the motions and 'ticking boxes'. This is far removed for the type of community consultation used in the SII integral policy development. The term 'active listening' was used to more accurately convey the dynamic interaction of the consultation process. Such consultation had an important component of 'report back' to the community on the results of the consultation, the final report and recommendations, and feedback regarding implementation (South Australian Social Inclusion Board, 2009). This level of authentic consultation gave a level of community mandate to the work of the SII. The feedback to the community was also a briefing on the implicit value as well as the scope of integrated policy and program development.

Innovations that ICANs have produced to respond to the local needs of young people disengaged or disengaging from education, include partnerships between a local secondary host school, youth agencies, government social security department, public housing agency, local government council, and TAFE SA (Patterson, 2011a). A further ICAN program called Gawler 15 was the formation of an 'accredited hospitality training program for young people aged 16-18 years', who had disengaged from learning and earning (Koen \& Duigan, $2008,2011)$. This program was the idea of local businesses because of a skill shortage and so was embedded in local needs and the local context.

The ICAN integrated work received its mandate and empowerment from government, its integrated approach from the Social Inclusion Board and its innovative spirit through locally based public participation and the development of partnerships. The policy decision to adopt the ICAN model was made by Cabinet on the recommendation of the Social Inclusion Board. The use of SII mechanism in a consultation process, discussion and dialogue with the Education Department and a wide range of other Departments required the power and force of the SII 'clash' and 'tension' model of horizontal policy development, and the use of the important skills of collaboration and coordination with government departments. The Board through the Social Inclusion Unit maintained a monitoring and evalua- 
tion role of the ICAN program. The ICAN concept is countercultural to the standard school paradigm. How was such a program embraced by government and ultimately by the Education system of the Government? How was it given status and priority?

\section{Sustainable Integrative Practices}

In the case example above of the ICANs, use of power, authority and mandate were essential qualities for the success of this integrated work. The movement from an issue that needed to be addressed, in this case school retention levels, and the effective implementation of the ICANs was an exercise in integrative practice. The components of this integrative mechanism were multiple. A clear need, positional power, administrative power, championing and active interest by the Premier, expert power through the composition of the Board and the Unit, structured administrative connectors through interdepartmental committees and a grounding in public participation, were all essential.

The authority had to come from the head of government, the Premier of South Australia, so that the level of delegated authority could cross departmental (silo) boundaries with legitimacy and power. A further important quality in producing integrated policy and programs was the level of independence given to the Social Inclusion Board and its Unit. There were no restrictions on policy innovation, other than their commitment to evidence based research, and the pragmatic realities that their policy recommendations needed the approval of Treasury and the Cabinet. The Premier changed the administrative arrangements so that Chief Executives of Government Departments were not only responsible to their (silo) Minister but were also directly responsible to him for Social Inclusion work. He also assumed the role as Minister for Social Inclusion as well as that of Premier. The Premier and the Chair of the Social Inclusion Board worked as a team in achieving social inclusion outcomes and would communicate during each week to monitor all social inclusion work and the cooperation or otherwise of Departments.

Inter-ministerial Committees for each SII mandated social issue were established and attended by the Chair and Director of the Social Inclusion Board where reports were given regarding the progress and performance of departments. These committees were a crucial part of the mechanism to ensure momentum for integrated policy development and program implementation was maintained, and were used to address barriers to integration. Membership of the Interministerial Committee would be on a recommendation of the Chair of the Board and would encompass the range of departments who would be involved in the joined up and integrative policy development and implementation plan. In the final year of the operation of the SII, in order to streamline and create efficiencies, all Inter-ministerial Committees dealing with SII references were collapsed into one Social Inclusion Cabinet Committee with the Premier as Chair and the Chair of the Social Inclusion Board, as well as the Director of the Social Inclusion Unit in attendance.

In addition the Chair of the Social Inclusion Board/ Commissioner was a member of the Executive Committee of State Cabinet. One major role of this Cabinet sub-committee was the monitoring and evaluation of the performance of Chief Executives of Government Departments in relation to the South Australian Strategic Plan, including social inclusion targets. This gave the Chair of the Social Inclusion Board a significant role with direct impact on the management of government departments. The Social Inclusion Board, made up of approximately ten social policy experts and experts in the mechanism of government, was given independent authority to develop innovative, integrated social inclusion policy. The power and authority given to the Chair of the Board and Commissioner for Social Inclusion enabled action to use the delegated authority of the head of government and to bridge across departmental boundaries. The Social Inclusion Unit, with its independent policy development role, also had a monitoring and evaluation role of the implementation of integrated policy and programs. Blocks and obstacles to the successful implementation of integrated plans would be referred to the Chair of the Board/Commissioner who would dialogue with the Premier or particular Minister or Chief Executive, to remove the obstacle, usually bureaucratic or programmatic difficulties.

In the case of the mandate given to the Social Inclusion Board to increase school retention, the initial responses from some in the lead department, the Education Department, included resistance to the idea that non educationalists and non-education department staff would be put in charge of what was seen as an education issue and an initial lack of cooperation in the sharing of data upon request from the Social Inclusion Unit. The use of power and authority, as well as persuasion and the building of trusting relationships to work together, as instructed by government, were all necessary to overcome the above obstacles and to build commitment and momentum to achieve integrated policies.

Fundamental to integrative policy and program development was the use of a deliberate mechanism, with the above mentioned qualities. The head of government's words, as the SII was being established, give an indication of the expected dynamic.

Both the Board and the Unit will ensure that plans of action are not watered down or bogged down in departments. That is why the published targets will be so important. There will be no alibis accepted for unnecessary delays and no excuses accepted for a lack of resolve in delivering results. (Newman, Biedrzycki, Patterson, \& Baum, 2007, p. 26) 
Navigating tensions was an ongoing aspect of the work of the Social Inclusion Board and Unit, noted by commentators such as Newman, Biedrzycki, Patterson and Baum (2007) and Patterson (2011a; 2011b). Patterson, for example, in analysis of the SII School Retention Action Plan, documents the challenges in gaining commitment from within government departments, and the repeated conflicts that arose which she attributes to different agency time rhythms and expectations about what should be achieved by when. Noteworthy is her point that tensions arise when there is a sense of 'disconnect' between those devising policy and those charged with implementing it (Patterson, 2011b, pp. 83-93). Newman, Biedrzycki, Patterson and Baum (2007) describes a more fundamental tension between the SII and Departmental bureaucracy that developed early in the life of the SII. This tension was because the SII wanted to bring about '...system change, whereby government agencies would move from the traditional silo approach where they worked predominately alone, to a joined up government approach so that the complexities of the causes of social exclusion could be identified and joined up solutions could be formulated' (Newman, Biedrzycki, Patterson, \& Baum, 2007, p. 59, italics in original).

Yet tension is inevitable in integrative work. Martin and Austen capture this in writing:

...choices inevitably involve tensions-what appears to be a trade-off in which the choosing of one option precludes another attractive option. Or using one resource renders that resource unavailable to others. Tension, by its very nature, compels leaders to make choices of some kind. Maintaining the status quo, typically is not an option. To move ahead, there's no choice but to choose. $(1999$, p. 2)

While not articulated at the time, a hindsight perspective of the mechanism of the SII could view it as a radical approach designed to create an inner tension within government in order to produce a 'clash' between the vertical role of the silos of government (based in Australia on the Westminster system of distinct Ministerial portfolio responsibility and hierarchical departmental authority and decision making) and the horizontal role of integrative policy work across government departments.

The work of the SII as such, was counter to the model of separate Ministerial led departmental authority, and chain of command and control, in each department. The underlying assumption for this approach of creating a system of 'tension' and 'clash' was that the hegemony of the vertical silo system would always dominate the policy agenda, because government departments were established in clear lineal authority structures under Ministerial authority. This had the weight of history behind it as the norm in the executive function of government bureaucracy throughout Australia. Unless the horizontal integrative work was given power, force and legitimacy to achieve its work and implement change it would fail to bring about integrative policy development.

Furthermore the competitive nature of Ministerial government centred on seeking funds for departmental programs through an annual budget process and competitive Cabinet meetings. This reinforced the hegemony of the vertical siloed structure of government; they would always dominate unless there was an alternative. Consequently, a further and perhaps underlying premise of the work of the SII was that calls for coordination, cooperation and integrative policy work are hollow without horizontal mechanisms which challenge vertical power. In Weberian terms the work of the SII was an exercise in the simultaneous use of charismatic authority and creation of counter forces to the historical exercise of legal/rational authority.

The role of the Social Inclusion Board and Unit was to ensure that departments delivered on targets that were publicly enunciated. Institutionally derived tensions occurred because the SII established their goals and targets within a political and electoral cycle whereas the bureaucracy of government departments were more focused on time frames within their own departmental capacity. Tensions also occurred because the work of the SII could be seen, in the words of interviewees reported in the Newman, Biedrzycki, Patterson and Baum rapid appraisal study 'as an implicit criticism of previous action, with agencies feeling somewhat threatened by the existence of a separate unit responsible for certain key issues' $(2007$, p. 52). The duality of accountability was also a source of tension between departments and the SII because departments were required to produce regular reports on the social inclusion work they had been given as part of an integrated plan, as well as respond to their regular departmental responsibilities (Newman, Biedrzycki, Patterson, \& Baum, 2007, p. 53).

It is within this broad context that the integrated policy work produced the ICAN concept and put it into structure and action. The Social Inclusion Board and the Social Inclusion Unit gave the ICANs political and bureaucratic protection. Monitoring the implementation of the ICANs meant that personnel problems, funding problems, communication difficulties, and any resistance to change could be quickly confronted and resolved. Within two years the ICANs had developed a status of their own and with positive evaluations of their work indicating high rates of success in reengaging young people with learning and/or opportunities for paid employment, the ICANs were able to proceed without any further support necessary from the SII (Koen and Duigan, 2008, 2011). As importantly, the ICANs were one piece in the intervention jigsaw seeking to increase school retention rates, which fol- 
lowing the national trend, have risen in SA from the 1999 figure of $67 \%$, to $86.3 \%$ in 2011 (ABS, 2012).

\section{Conclusion}

While an inner tension is well recognised in the relationship between social inclusion and wealth redistribution, social inclusion as a concept and policy method can provide a powerful mode for the enhancement of the lives of citizens in participatory community, particularly the most disadvantaged with complex and multiple needs. The South Australian example is given as a case in point.

Collaboration, cooperation and coordination are essential strategies and skills to be used in the process of developing and implementing integrative policy and program. They are words that resonate well in the bureaucratic and policy development world. Yet, so much of 'whole of government' or integrative work seems to fall short of its goal. There is a missing component. A mechanism of horizontal power is necessary as the foundation on which the above skills need to operate. The ICAN programme is counter cultural. Delivered in a social inclusion context it placed the multiple needs of young people at the heart of its attention in reengaging them with learning. It did this outside the culture and power base of the education bureaucracy which initially refused to view the problem as needing integrative solutions. To do this it needed its own power base. The mechanism of 'tension' and 'clash' used by the South Australian Social Inclusion Board and Unit between 2002-2011 achieved goals and outcomes in reducing homelessness, a reform of the mental health system, increasing school retention, a major report on disability reform, and juvenile justice. While the SII ended in October 2011 when a new head of government was installed, ICANs have become embedded in South Australia's policy agenda and are now supported and promoted by the Education Department and the education system.

A further question to be considered is, apart from political contingencies, can a power mechanism such as the SII be sustainable? Can it become part of the system and continue to fulfil its mandate? This is a question for further debate. The need for the SII to respond to many barriers to its work, the regularity of bureaucratic obstacles, and the reality that in its political demise, it would seem that bureaucratic practice moved effortlessly back to pre SII operations does not bode well for a positive response to these questions. The latter comment is of course a perspective, and there will be multiple views about this.

The SII is a model worthy of further examination in the cause of producing better ways to integrate policy and program. But ultimately the choice of models is a matter of politics and power. As Rittel and Webber write: 'Whichever the tactic, though, it should be clear that the expert is also a player in a political game, seeking to promote his (sic) private vision of goodness over others'. Planning is a component of politics. There is no escaping that truism' (1973, p. 169). There is also no escaping the continued need for critical appraisal of the structural factors that impact on the success or failure of what is known as 'joined up policy and program', whole of government work, or integrated policy and program development.

\section{Acknowledgements}

The authors gratefully acknowledge and thank the anonymous reviewers for comments on earlier versions of this paper.

\section{Conflicts of Interest}

The authors declare no conflicts of interest.

\section{References}

Australian Bureau of Statistics (ABS). (2012). Australian Social Trends: Cat. 4102 Education and Training SA Summary 1997-2011. Retrieved from: http://www. abs.gov.au/ausstats/abs@.nsf/mf/4102.0

Bevir, M. (2009). Key Concepts in Governance. London, UK: SAGE Publications.

Black, L. (2013). The Social Licence to Operate. Your Management Framework for Complex Times. Oxford, UK: Do Sustainability.

Boutellis, A. (2013). Driving the System Apart? A Study of United Nations Integration and Integrated Strategic Planning. New York, NY: International Peace Institute.

Bryson, L., \& Mowbray, M. (1981). 'Community': the spray on solution. Australian Journal of Social Issues, 16(4), 244-256.

Bryson, L., \& Verity, F. (2009). Australia: From Wage Earners to Neo-Liberal Welfare State. In Craig \& P. Alcock (Eds.), International Social Policy: Welfare regimes in the developed world (2nd edition, pp.6687). UK: Palgrave.

Cappo, D. (2002). Social Inclusion, Participation and Empowerment. Speech Given to the Australian Council of Social Services National Congress. $28^{\text {th }}$ November, Hobart.

Christensen, T., \& Lægreid, P. (2007). The Whole-ofGovernment Approach to Public Sector Reform. Public Administration Review, 67(6), 1059-1066.

Corbett, T., \& Noyes, J. (2008). Human Services Systems Integration: A Conceptual Framework. Institute for Research on Poverty Discussion Paper No. 1333-08. Madison: University of Wisconsin.

Davies, J. S. (2009). The Limits of Joined-Up Government: Towards a Political Analysis. Public Administration, 87(1), 80-96. 
De Lombaerde, P., \& lapadre, P. (2008). International Integration and Societal Progress: A Critical Review of Globalisation Indicators. In OECD Statistics, Knowledge and Policy: Measuring and Fostering the Progress of Societies. Paris: OECD Publishing.

Eriksen, E. O., \& Fossum, J. E. (1999). The European Union and post-national integration. Norway: ARENA.

Fine, M., Pancharatnam, K., \& Thomson, C. (2000). Coordinated and Integrated Human Service Delivery Models. NSW: Social Policy Research Centre and University of New South Wales.

Gray, J. (2000). Inclusion: A Radical Critique. In P. Askonas \& A. Stewart (Eds.), Social Inclusion: Possibilities and Tensions (pp. 19-36). Basingstoke, UK: Palgrave Macmillan.

Hartman, C., \& Squires, G. (2009). Integration Exhaustion, Race Fatigue and the American Dream. Administrator, April. Retrieved from http://www.planners network.org/2009/04/integration-exhaustion-racefatigue-and-the-american-dream

Horsell, C. (2010). Report on Research: Social Inclusion and Homelessness in South Australia-A Critical Appraisal. Parity, 23(4), 31-33.

Jennings, E. T., Jr., \& Krane. D. (1994). Coordination and welfare reform: The quest for the philosopher's stone. Public Administration Review, 54(4), 341-348.

Koen, S., \& Duigan, P. (2008). Forging Brighter Futures: Innovative Approaches to Improving Propects for At Risk Young People. The History and Future of Social Innovation Conference, Adelaide 19-21 June. Retrieved from http://w3.unisa.edu.au/hawkeinstitu te/publications/social-innovation/koen-duigan.pdf

Koen, S., \& Duigan, P. (2011). Re-engaging young people in learning: the ICAN experience. In T. Stehlik and J. Patterson (Eds.), Changing the paradigm: Education as the key to a socially inclusive future. Queensland: Post Pressed.

Koikkalainen, P. (2011). Social Inclusion. In M. Bevir (Ed.), The SAGE handbook of governance. London: SAGE Publications.

Levitas, R. (2005). The Inclusive Society? Social Exclusion and New Labour (2nd edition). UK: Macmillan.

Lynn, L. E., Jr. (1998). The new public management: how to transform a theme into a legacy. Public $A d$ ministration Review, 58(3): 231-237.

Martin, R., \& Austen, H. (1999). The Art of Integrative Thinking. Rotman Management. Fall 2-5. Retrieved from http://www.2.rotman.utoronto.ca/rogermart in/the\%20art\%20of\%20integrative\%20thinking.pdf

Mulgan, G. (2005). Joined-Up Government: Past, Present, and Future. In V. Bogdanor (Ed.), Joined-Up Government. Oxford: Oxford University Press.

Mulgan, G. (2009). The Art of Public Strategy: Mobilizing Power and Knowledge for the Common Good.
Oxford: Oxford University Press.

Newman, L., Biedrzycki, K., Patterson J., \& Baum, F. (2007). A rapid appraisal case study of the South Australia's Social Inclusion Initiative. Adelaide: Department of Premier and Cabinet.

Patterson, J. (2011a). Challenging the paradigm: education and social inclusion. In T. Stehlik and J. Patterson (Eds.), Changing the paradigm: Education as the key to a socially inclusive future. Queensland: Post Pressed.

Patterson, J. (2011b). We know what to do but we don't always do it. In T. Stehlik and J. Patterson (Eds.), Changing the paradigm: Education as the key to a socially inclusive future. Queensland: Post Pressed.

Pickles, E. (2013). Uniting our Communities: Integration in 2013. Retrieved from: https://www.gov.uk/ government/speeches/uniting-our-communities-in tegration-in-2013

Plant, R. (2009). Community and Ideology (Routledge Revivals): An Essay in Applied Social Philosophy. Oxford: Routledge.

Australian Productivity Commission. (2010). Contribution of the not-for-profit sector. Canberra: Australian Government.

Ragan, M. (2003). Building Better Human Service Systems: Integration Services for Income Support and Related Programs. Albany. New York: The Nelson A. Rockefeller Institute of Government.

Rittel, H., \& Webber, M. (1973). Dilemmas in a General Theory of Planning. Policy Sciences, 4, 155-169.

Rousseau, D. (2011). Reinforcing the Micro/Macro Bridge: Organisational Thinking and Pluralistic Vehicles. Journal of Management, 37(2), 429-442.

South Australian Labor Party. (2002). Labor's Social Inclusion Initiative: Labor's Plans for Government. Adelaide: South Australian Labor Party.

South Australian Social Inclusion Board. (2004). Making the Connections. Adelaide: Department of Premer and Cabinet.

South Australian Social Inclusion Board. (2009). People and Community at the Heart of Systems and Bureaucracy: South Australia's Social Inclusion Initiative. Adelaide: Department of Premer and Cabinet.

Stehlik T., \& Patterson, J. (2011). Changing the paradigm: Education as the key to a socially inclusive future. Queensland: Post Pressed.

Ward, P., Meyer, S., Verity, F., Gill, T., \& Luong, T. (2011). Complex problems require complex solutions: the utility of social quality theory for addressing the Social Determinants of Health. BioMed Central, 11, 630. doi: 10.1186/1471-2458-11-630.

Wilber, K. (2000). Integral psychology. Boston, Massachusetts: Shambhala Publications. 


\section{About the Authors}

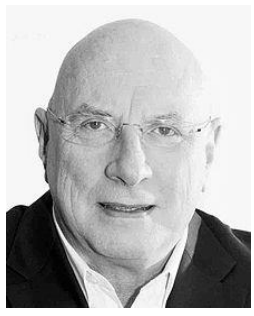

\section{David Cappo}

David Cappo is a Senior Research Fellow at Flinders University, South Australia (SA). He is a qualified social worker, with extensive experience in social policy development. He led the Social Inclusion Initiative in South Australia between 2002-2011. In 2002 he was appointed Chair of the newly established South Australian Social Inclusion Board, and subsequently, Commissioner for Social Inclusion. $\mathrm{He}$ is a Catholic Priest in SA.

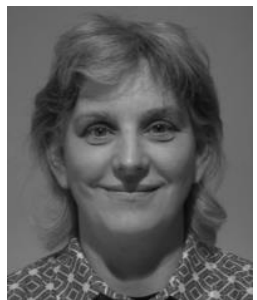

\section{Dr. Fiona Verity}

Fiona Verity is Professor, Social and Policy Studies, Flinders University. Her research focus is in the area of social development, and recent projects include exploring the impacts of risk management on civil society, affordable food access and corporate social responsibility. Her previous position was Dean, School of Social and Policy Studies, Flinders University. 